\title{
STRATEGI MEMILIKI TEMPAT TINGGAL PADA BURUH PRODUKSI GAMPING DI DESA GRENDEN KECAMATAN PUGER KABUPATEN JEMBER
}

\author{
Nur Wulan ${ }^{1}$, Sri Kantun ${ }^{1}$, Joko Widodo ${ }^{1}$ \\ ${ }^{1}$ Program Studi Pendidikan Ekonomi, Fakultas Keguruan dan Ilmu Pendidikan, Universitas Jember
}

\begin{abstract}
The purpose of the research was analyzing about how the strategy which was done by limestone production labor. Related to the strategy that was done by them, therefore they could have homestay for their family. The area determination of the research was determined by area purposive method, which was done as deliberate by the researcher. The researcher chosen Grenden, Puger, Jember. In this research, there are four family limestone production labor and four supporting informants from their neighbors. The data collection method used by the researcher including interview method, observation method, and documentation method. The analysis data which was used in this research consist of some stages, they were the reduction data, the presentation data, and drawing conclusion. The result of the study showed that the limestone production labor had homestay with proper conditions and preparations in owning it more than 5 years in the average. The limestone production labor who had homestay certainly applied many kind of strategy to be able to have their own homestay. These strategies were doing diversity working, making social network, saving money, and the obligation system. All of the main four informants did diversity working to increase the income. They also saved money with different ways. Meanwhile, the main three informant made social network by asking for assistance in their neighbors to build their homestay. And there is one from main informant did the obligation system with borrowing money and paying it by instalment which was appropriate with the engagement. By using these strategies, it gave the evidence that limestone production labor in Grenden, Puger, Jember could have their homestay.
\end{abstract}

Keywords: strategy, owning homestay, limestone production labor

\section{PENDAHULUAN}

Setiap keluarga pasti membutuhkan tempat tinggal, karena tempat tinggal merupakan kebutuhan pokok yang harus dipenuhi oleh setiap keluarga untuk melangsungkan hidupnya. Tidak semua keluarga bisa memiliki tempat tinggal pribadi, meskipun belum memiliki tempat tinggal pribadi namun bisa bertempat tinggal di kos-kosan, kontrakan, rumah pribadi, maupun di rumah kerabat keluarganya. Memiliki tempat tinggal pribadi tentu harapan bagi semua keluarga, dan setiap keluarga pasti memiliki tempat tinggal idamannya masing-masing.

Dengan memiliki tempat tinggal pribadi tentu memberikan banyak keuntungan, salah satu keuntungannya adalah seseorang bisa lebih hemat dan mengatur keuangannya karena dengan memiliki tempat tinggal pribadi seseorang tidak perlu memikirkan biaya sewa rumah perbulan/pertahun. Tempat tinggal mempunyai banyak fungsi salah satunya yaitu fungsi sosial dan ekonomi. Fungsi sosial biasanya digunakan untuk melakukan kegiatan sosial dan berinteraksi dengan masyarakat di sekitar seperti untuk pengajian, arisan, berkumpul dengan kerabat ataupun tetangga sekitar. Sedangkan fungsi ekonomi biasanya digunakan untuk kegiatan yang bisa menghasilkan nilai tambah secara ekonomi seperti untuk berjualan ataupun sejenisnya.

Memiliki tempat tinggal pribadi tentu harapan bagi semua keluarga. Mungkin bagi seseorang yang berpenghasilan tinggi untuk memiliki tempat tinggal pribadi bukanlah hal yang sulit. Sebaliknya untuk masyarakat yang berpenghasilan menengah kebawah tempat tinggal pribadi bagi mereka adalah salah satu kebutuhan yang sulit untuk dipenuhinya, kebutuhan tersebut tentu membutuhkan waktu yang sangat lama dan bertahun-tahun, karena ada yang lebih 
penting yang harus dipenuhi terlebih dahulu seperti pangan dan sandang. Termasuk bagi buruh produksi gamping yang ada di Desa Grenden Kecamatan Puger Kabupaten Jember yang penghasilannya tergolong kecil dan pekerjaannya tidak tetap tentu hal itu akan sulit bagi para buruh untuk memenuhi kebutuhan tempat tinggal pribadi. Mereka harus membutuhkan waktu yang cukup lama supaya bisa memiliki tempat tinggal pribadi.

Harga tanah dan bahan bangunan yang tidak murah tentunya menjadi beban tersendiri bagi buruh produksi gamping untuk memenuhi kebutuhan tempat tinggal pribadinya. Berikut ini adalah tabel macam-macam harga tanah di Kecamatan Puger Khususnya di Desa Grenden Kecamatan Puger Kabupaten Jember.

Tabel 1.1 Daftar harga tanah di Desa Grenden

\begin{tabular}{lll}
\hline No. & Harga Tanah $/$ Meter & Keterangan \\
\hline 1. & $150 \mathrm{ribu} /$ meter & Tanah pinggir jalan \\
2. & $125 \mathrm{ribu} /$ meter & Tanah agak masuk \\
3. & $75 \mathrm{ribu} /$ meter & Tanah yang jauh dari jalan \\
\hline & Sumber $:$ Kantor Kepala Desa Grenden tahun 2016
\end{tabular}

Tabel di atas menunjukan harga tanah di Desa Grenden, harga tanah yang tidak murah berkisar dari 75 ribu sampai dengan 150 ribu tentunya tidak menyurutkan niat buruh produksi gamping untuk dapat memenuhi kebutuhan tempat tinggal pribadinya.

Berdasarkan hasil wawancara, dari informasi awal sebagian buruh produksi gamping ada yang sudah memiliki tempat tinggal pribadi dan sebagian lagi belum memiliki tempat tinggal pribadi dan sebagian lagi masi bertempat tinggal dirumah mertuanya. Memiliki tempat tinggal pribadi tentu saja bukan hal yang mudah bagi para buruh produksi gamping di Desa Grenden Kecamatan Puger Kabupaten Jember. Berbagai usaha dan cara di lakukan oleh para buruh gamping untuk dapat memiliki rumah pribadi mulai dari menabung, menghemat bahkan menghutang. Setiap buruh produksi mempunyai cara atau strategi masing-masing yang di gunakan agar dapat memiliki tempat tinggal pribadi.

Untuk memiliki tempat tinggal pribadi, buruh produksi batu gamping tentu memiliki strategi tersendiri yang dilakukan sehingga mampu memiliki tempat tinggal pribadi. Menurut Suharto (2009:29) strategi merupakan kemampuan seseorang dalam menerapkan seperangkat cara untuk mengatasi berbagai permasalahan yang melengkapi kehidupannya, strategi penanganan masalah ini pada dasarnya merupakan kemampuan segenap anggota keluarga dalam mengelola segenap aset yang dimilikinya.

Corner (dalam Kusnadi, 2000:8) menyatakan strategi-strategi dalam memenuhi kebutuhan yang dapat dilakukan oleh kalangan penduduk miskin antara lain:

1. Melakukan keanekaragaman pekerjaan, dengan melakukan keanekaragaman pekerjaan bertujuan agar dapat memperoleh hasil tambahan. Pekerjaan-pekerjaan yang tersedia di desa akan tetap dilakukan, kendatipun upah yang diperolehnya rendah. Melakukan keanekaragaman pekerjaan merupakan salah satu cara yang dilakukan oleh keluarga yang berpenghasilan rendah karna pendapatan yang minimal sehingga mereka tidak tergantung pada satu pekerjaan.

2. Mengurangi tingkat konsumsi sehari-hari. Bekerja lebih banyak meskipun lebih sedikit masukan. Strategi yang bersifat ekonomis ini ditempuh untuk mengurangi tingkat kebutuhan 
konsumsi sehari-hari. Dengan strategi ini seseorang dapat menerapkan hidup hemat. Hidup hemat dapat diterapkan oleh seseorang dengan cara menabung.

3. Melakukan jaringan sosial. Sistem kekerabatan, ketetanggaan, dan pengaturan secara tukar menukar secara timbal balik. Merupakan sumberdaya yang sangat berharga bagi penduduk miskin. Dalam menghadapi penghasilan dan peluang yang semakin merosot tajam, penduduk miskin ini masih dapat bertahan dengan harapan dari para kerabat, keluarga dan tetangga-tetangganya serta teman-teman berbagi kelebihan apapun yang mereka miliki. Strategi lain yang dapat dilakukan seseorang untuk dapat memenuhi kebutuhan hidupnya termasuk untuk memiliki tempat tinggal selai strategi yang telah disebutkan di atas seseorang juga dapat menerapkan dengan dengan cara hutang piutang.

4. Sistem hutang piutang. Menurut Muslich (2010:274) menyatakan bahwa definisi dari hutang piutang adalah memberikan sesuatu yang menjadi hak milik pemberi kepada peminjam dengan pengembalian dikemudian hari sesuai dengan perjanjian dengan jumlah yang sama.

Berdasarkan latar belakang di atas, maka perlu dirumuskan bagaimanakah Strategi yang dilakukan oleh buruh produksi gamping di Desa Grenden Kecamatan Puger Kabupaten Jember untuk memiliki tempat tinggal.

\section{METODE PENELITIAN}

Penelitian ini merupakan penelitian deskriptif dengan pendekatan kualitatif. Untuk mendeskripsikan tentang strategi memiliki tempat tinggal yang dilakukan oleh buruh produksi gamping di Desa Grenden Kecamatan Puger Kabupaten Jember Penentuan lokasi penelitian ditentukan dengan metode Purposive Area, yaitu di Desa Grenden Kecamatan Puger Kabupaten Jember, karena di Desa Grenden banyak terdapat industri kecil pengolahan batu gamping dan sebagian besar masyarakat di Desa Grenden bekerja sebagai buruh produksi gamping dengan pendapatan yang minimal namun sudah banyak yang memiliki tempat tinggal sendiri.

Sumber data dalam penelitian ini meliputi sumber data yang diperoleh dari 4 keluarga informan utama dan 4 informan pendukung. Informan utama dalam penelitian ini adalah keluarga buruh produksi gamping di Desa Grenden Kecamatan Puger Kabupaten Jember yang sudah memiliki tempat tinggal. Sedangkan informan pendukung dalam penelitian ini adalah tetangga atau orang yang sudah memberikan bantuan kepada informan utama yang ada di Desa Grenden Kecamatan Puger Kabupaten Jember. Metode pengumpulan data yang digunakan terdiri dari wawancara, observasi dan dokumen. Analisis data yang digunakan adalah reduksi data, penyajian data, dan penarikan kesimpulan.

\section{HASIL DAN PEMBAHASAN}

\section{Hasil Penelitian}

Data utama yang dikumpulkan merupakan data yang diperoleh dari hasil observasi dan wawancara yang dilakukan oleh peneliti terhadap subyek penelitian yaitu buruh produksi gamping yang ada di Desa Grenden Kecamatan Puger Kabupaten Jember. Adapun strategi yang dilakuka oleh buruh produksi gamping diantaranya yaitu:

1. Melakukan Keanekaragaman Pekerjaan

Strategi yang dapat dilakukan oleh buruh produksi gamping untuk dapat memenuhi kebutuhan tempat tinggalnya adalah dengan melakukan pekerjaan sampingan diluar pekerjaan 
pokoknya. Biasanya pekerjaan sampingan dilakukan oleh informan diluar waktu kerjanya sebagai buruh produksi gamping yaitu misalnya dengan bekerja sebagai buruh tani dan dengan memelihara hewan milik orang lain. Informan utama memiliki perbedaan dalam memilih pekerjaan sampingan yang dilakukannya sesuai dengan kemampuan dan kesempatan yang ada.

Seperti yang dilakukan oleh informan utama yaitu keluarga bapak S, bapak M, bapak SG dan bapak R, mereka melakukan keanekaragaman dengan cara yang berbeda-beda. Bapak $\mathrm{S}$ melakukan keanekargaman pekerjaan dengan cara menjadi buruh tani dan memelihara sapi milik orang lain, selanjutnya bapak M melakukan keanekargaman pekerjaan dengan menjadi buruh pemelihara sapi milik orang lain dan memeilhara beberapa ekor ayam miliknya sendiri. Sedangkan bapak SG melakukan keanekaragaman pekerjaan dengan menjadi buruh srabutan dan memelihara ayam milik sendiri dan untuk bapak R melakukan keanekaragaman pekerjaan hanya dengan memelihara sapi milik orang lain saja. semua itu dilakukan oleh buruh produksi gamping dengan tujuan untuk bisa mendapatkan pendapatan tambahan supaya bisa membantu mempercepat keluarga mereka untuk memiliki tempat tinggal sendiri.

2. Menabung

Strategi lain yang dapat membantu buruh produksi gamping untuk dapat memenuhi kebutuhan tempat tinggalnya yaitu dengan cara menabung. Dalam memenuhi kebutuhan tempat tinggalnya tentu saja buruh produksi gamping di Desa Grenden Kecamatan Puger Kabupaten Jember tidak hanya melakukan pekerjaan sampingan saja, mereka juga harus menyisihkan pendapatannya untuk ditabung dengan tujuan nanti bisa untuk mempersiapkan biaya yang dibutuhkan untuk membangun tempat tinggalnya. Setiap buruh produksi gamping tentunya memiliki cara menabung yang berbeda-beda sesuai dengan kemampuan masing-masing.

Menabung yang dilakukan oleh keluarga buruh produksi gamping memiliki cara tersendiri tergantung dari kemampuan masing-masing dan cara yang paling mudah bagi mereka. Seperti yang dilakukan oleh keluarga bapak S, beliau menabungkan uangnya dengan cara membelikan bahan bangunan sedikit demi sedikit yang diperlukan untuk membangun tempat tinggalnya, selanjutnya menabung yang dilakukan oleh keluarga bapak $\mathrm{M}$ yaitu mengumpulkan uangnya dengan cara membeli emas, ketika tabungannya dianggap cukup maka emas tersebut akan dijual untuk biaya membangun tempat tinggalnya. Berbeda dengan keluarga bapak SG, keluarga mereka menabungkan uangnya dengan cara menyimpannya dicelengan, hal itu dilakukan dengan alasan lebih mudah di ambil ketika ada keperluan mendesak. Sedangkan untuk keluarga bapak R lebih memilih menabungkan uangnya kepada juragan gamping tempat beliau bekerja dengan alasan takut uang yang ditabungkan akan gampang terpakai untuk memenuhi kebutuhan yang tidak begitu penting. Semua itu dilakukan dengan harapan bisa mempersiapkandan lebih mempercepat keluarga mereka memiliki tempat tinggal.

3. Melakukan Jaringan Sosial

Strategi yang bisa dilakukan oleh buruh produksi gamping selain dengan melakukan keanekaragaman pekerjaan dan menabung yaitu dengan melakukan jaringan sosial. Jaringan sosial yang dimaksud adalah dengan membangun komunikasi, saling percaya dan membantu satu sama lain baik dari individu ke individu, individu ke kelompok, maupun dari kelomok ke kelompok didalam masyarakat.

Tidak semua informan utama melakukan jaringan sosial untuk dapat memiliki tempat tinggal pribadinya, namun ada juga informan utama yang melakukan jaringan sosial untuk 
dapat memiliki tempat tinggalnya seperti yang dilakukan bapak $\mathrm{S}$, beliau memanfaatkan jaringan sosial dengan meminta bantuan kepada pemilik toko bangunan agar bisa mencicil membeli bahan-bahan bangunan yang diperlukan oleh keluarga bapak S untuk membangun tempat tinggal. Sedangkan bapak SG dan bapak R melakukan jaringan sosial dengan cara yang sama yaitu dengan meminta bantuan berupa tenagga dengan bergotong royong untuk menbantu membangun tempat tinggalnya, karna keterbatasan biaya sehingga meminta bantuan dengan cara bergotong royong untuk menghemat biaya yang dikeluarkan ketika membangun tempat tinggalnya.

\section{Sistem Hutang Piutang}

Strategi lain yang bisa dilakukan oleh buruh produksi gamping di Desa Grenden Kecamatan Puger Kabupaten Jember selain dengan melakukan keanekaragaman pekerjaan, menabung dan membangun jaringan sosial maka bisa juga dengan cara sistem hutang. Hutang tersebut bisa berupa uang atau barang yang nanti pengembaliannya dalam jangka waktu tertentu baik dengan bunga ataupun tanpa bunga, kredit ini bisa dilakukan dibank ataupun kepada tetangga dan saudara.

Informan yang melakukan sistem hutang piutang hanya dilakukan oleh bapak M saja. Bapak M melakukan hutang karena kendala biaya yng dimiliki saat membangun tempat tinggalnya kurang sehingga beliau mencari cara untuk bisa menutupi kekurangan biaya tersebut dengan cara berhutang kepada saudaranya sendiri. Adapun pembayaran hutang tersebut dilakukang dengan cara mencicil sesuai kemampuan yang dimiliki oleh keluarga bapak M. Butuh waktu bertahun-tahun untuk bapak $M$ bisa melunasi hutangnya tesebut namun dengan cara berhutang keluarga bapak M lebih terbantu dan lebih mempercepat keluarga beliau untuk memiliki tempat tinggal sendiri.

\section{Pembahasan}

Berdasarkan hasil penelitian yang diperoleh dari buruh produksi gamping yang ada di Desa Grenden Kecamatan Puger Kabupaten Jember menunjukkan bahwa buruh produksi gamping bisa memiliki tempat tinggal dengan melakukan beberapa strategi yaitu dengan cara melakukan keanekaragaman pekerjaan, manabung dan melakukan jaringan sosial serta dengan sistem hutang piutang.

Adapun strategi yang pertama yaitu dengan melakukan keanekaragaman pekerjaan seperti yang dilakukan oleh bapak S. Bapak K membenarkan jika tetangganya tesebut tidak hanya melakukan satu pekerjaan saja, bapak K mengatakan bahwa bapak S juga sering kerja sebagai buruh tani dan memelihara sapi milik orang lain demi untuk menambah penghasilan dan bisa memiliki tempat tinggal sendiri. Hal tersebut sesuai dengan pernyataan Corner (dalam Kusnadi, 2000:8) yang menyatakan bahwa dengan melakukan keanekaragaman pekerjaan merupakan salah satu cara yang dilakukan dalam pemenuhan kebutuhan hidupnya, seperti kebutuhan tempat tinggal.

Selain strategi melakukan keanekaragaman pekerjaan buruh produksi gamping di Desa Grenden Kecamatan Puger Kabupaten Jember juga melakukan strategi lain yaitu dengan cara menabung. Seperti yang dilakukan oleh keluarga bapak SG, keluarga mereka berusaha untuk menabung agar dapat memiliki tempat tinggal sendiri. Pernyataan tersebut diperkuat dengan pengakuan dari bapak D tetangga dari bapak SG yang menerangkan keluarga bapak SG sering 
membeli celengan untuk menyimpan uangnya sedikit demi sedikit demi untuk mempersiapkan biaya yang dibutuhkan untuk membangun tempat tinggal untuk keluarganya. Fakta tersebut sesuai dengan pendapat Alexano (2012:67) yang menyatakan bahwa dengan menabung maka harus benar-benar dapat menyisihkan uang untuk tidak digunakan dan disimpan sehingga jumlahnya semakin besar, dan pada saatnya nanti uang tabungan tersebut dapat digunakan untuk keperluan lain seperti biaya pendidikan, memiliki rumah ataupun membeli kendaraan.

Buruh produksi gamping juga melakuka strategi lain yaidu dengan melakukan jaringan sosial. Seperti yang dilakuka oleh keluarga bapak R beliau meminta bantuan berupa gotong royong untuk membangun tempat tinggalnya. Hal tersebut diperkuat dengan pernyataan bapak MS tetangga bapak R, beliau membenarkan bahwa keluarga bapak R meminta bantuan saat membangun tempat tinggalnya, pada saat itu bapak MS juga ikut membantu membangun tempat tinggal milik keluarga bapak R. Hal ini sesuai dengan pendapat dari Kusnadi (2002:8) yang mengatakan bahwa semakin banyak berhubungan baik dengan banyak orang maka akan semakin banyak orang yang membantu ketika mendapat kesulitan. Bantuan tersebut seperti pinjam meminjam sumber daya ekonomi dan jasa merupakan karakteristik hubungan sosial yang sangat penting.

Selain strategi ketiga di atas buruh produksi gamping juga bisa melakukan strategi lain yaitu dengan sistem hutang untuk menambah biaya yang dibutuhkan untuk membangun tempat tinggalnya. Strategi ini dilakukan oleh keluarga bapak M, beliau meminjam uang untuk menutupi kekurangan biaya untuk membangun tempat tinggalnya. Hal tersebut dibenarkan oleh saudara dari bapak M yaitu ibu WS. Beliau menerangkan bahwa bapak M meminjam uang kepada ibu WS dengan sistem pembayaran dicicil selama beberapa tahun untuk menabah biaya untuk membangun tempat tinggalnya. Pernyataan tersebut sesuai dengan pendapat dari Nugroho (2001:33) mendefinisikan bahwa hutang piutang adalah memberikan sesuatu yang menjadi hak milik pembari pinjaman kepada peminjam dengan pengembalian dikemudian hari dengan jumlah yang sama yang bertujuan untuk meringankan beban seseorang yang sedang mendapatkan kesulitan dalam kehidupannya.

Adanya penelitian ini, buruh produksi gamping di Desa Grenden Kecamatan Puger Kabupaten Jember dapat mengetahui bahwa mereka sudah melakukan berbagai macam strategi yang dilakuka dari hasil kerja kerasnya sendiri dalam pemenuhan kebutuhan tempat tinggalnya. Strategi yang dilakukan yaitu dengan melakukan keanekaragaman pekerjaan, menabung, melakukan jarungan sosial serta dengan sistem hutang piutang.

\section{KESIMPULAN DAN SARAN}

Berdasarkan hasil penelitian dan pembahasan yang sudah dilakukan oleh peneliti kepada informan utama mengenai strategi pemenuhan kebutuhan tempat tinggal di Desa Grenden Kecamatan Puger Kabupaten Jember, maka dapat disimpulkan bahwa usaha dalam pemenuhan kebutuhan tempat tinggal tersebut menggunakan strategi melakukan keanekaragaman pekerjaan, menabung dan dengan membangun jaringan sosial dan sistem hutang piutang. Waktu yang diperlukan buruh produksi gamping untuk dapat memenuhi tempat tinggal berkisar 6 tahun sampai dengan 10 tahun lamanya untuk mempersiapkan membangun tempat tinggalnya. Melalui strategi yang telah dilakukan tersebut, terbukti bahwa para buruh produksi gamping dapat memenuhi kebutuhan tempat tinggalnya. 
Berdasarkan kesimpulan dari penelitian ini, maka Sebaiknya buruh produksi gamping tetap melakukan pekerjaan sampingan dan menabung supaya bisa memperbaiki tempat tingganya lebih baik lagi dari sebelumnya dan bisa membeli perlengkapan lain untuk dapat memperlengkap fasilitas rumahnya.

\section{DAFTAR BACAAN}

Alexano, Poppy. 2012. Manajemen Keuangan Untuk Pemula dan Orang Awam. Jakarta: Laskar Aksara.

Kusnadi. 2000. Nelayan: Strategi Adaptasi dan Jaringan Sosial. Bandung: Humaniora Utama Pers.

Kusnadi. 2002. Konflik Sosial Nelayan: Kemiskinan dan Perebutan Sumberdaya Perikanan. Yogyakarta : LkiS Yogyakarta.

Nugroho, Heru. 2001 Uang, Rentenir dan Hutang Piutang di Jawa. Cetakan I. Yogyakarta: Ram Pustaka Pelajar.

Suharto, Edi. 2009. Kemiskinan Dan Perlindungan Sosial Di Indonesia. Bandung: Alfabeta. 